\title{
FAMI72A expression in circulating tumor cells for prediction of high-risk subgroups of colorectal
} cancer

\section{Chang $X u^{\prime}$ \\ Chunhong Zhang ${ }^{2}$ \\ Haowen Wang ${ }^{3}$ \\ Han Yang ${ }^{3}$ \\ Gang $\mathrm{Li}^{3}$ \\ Zhenghua $\mathrm{Fei}^{3}$ \\ Wenfeng $\mathrm{Li}^{1,3,4}$}

'Department of Colorectal Surgery, ${ }^{2}$ Department of Pharmacy,

${ }^{3}$ Department of Chemoradiotherapy, ${ }^{4}$ Laboratory for Interdisciplinary

Research, Institution for Translational Medicine, The First Affiliated Hospital of Wenzhou Medical University,

Wenzhou, People's Republic of China

\section{Correspondence: Wenfeng $\mathrm{Li}$}

Department of Chemoradiotherapy,

The First Affiliated Hospital of Wenzhou

Medical University, Shangcai village,

Nanbaixiang, Ouhai District, Wenzhou,

People's Republic of China

Tel +8657788002215

Email wflee_wmu@।63.com
This article was published in the following Dove Press journal:

OncoTargets and Therapy

30 March 2017

Number of times this article has been viewed

Objectives: Previous studies used enumerated prognosis and therapeutic effect in several ty showed that only enumerated CTCs were $s$ enoug reflect heterogeneity of tumors. Therefore, we classified different meta potentials on colorectal cancer (CRC) patients to improve the accuracy of p.ognosis CTCs.

Methods: Blood samples were a from 45 nary CRC patients. CTCs were enriched by blood filtration, and the RNA 1 situ hybridization menod was used to identify and discriminate subgroups of CTCs. Later, AM172A exp ssion in individual CTCs was measured.

Results: Three CTC subgro s (epithelial/ ophenotypic/mesenchymal CTCs) were identified using epithelial-resenchyma sition arkers. In our research, mesenchymal CTCs significantly increased a ng progression, including developing distant metastasis and vascular invasion. Fur rme, $72 \mathrm{~A}$ expression rate in mesenchymal CTCs was significantly higher at in e, elial CTCs, which suggested that FAM172A may correlate with tumor ma snancy. his hyp hesis was further verified by FAM172A expression in mesenchymal Cs strif for to mesenchymal CT a FAM172A expression may predict high-risk subgroups in stage II CRC.

Concl. on: Our research proved that CTCs could serve as feasible surrogate samples to detect gene expre,

ywords: colorectal cancer, circulating tumor cells, epithelial-mesenchymal transition, FA. $172 \mathrm{~A}$

\section{Introduction}

Despite improvements in surveillance and clinical treatment strategies, the prognosis of colorectal cancer (CRC) remains very poor due to high incidence of recurrence and metastasis; $\sim 20 \%-45 \%$ of those who undergo curative resection subsequently develop local tumor recurrence or metastasis at distant sites. ${ }^{1}$ The lack of effective methods for timely diagnosis and monitoring anticancer treatment response is the main obstacle preventing improvement of overall survival (OS) of patients with CRC.

Traditional clinicopathological parameters and serologic tumor markers offer limited information covering CRC diagnosis, prognosis prediction, and monitoring of the therapeutic response in a real-time manner. Therefore, there is an urgent need to develop a reliable and versatile method for discriminating high-risk factors of recurrent patients and continuous surveillance of antitumor treatment response. ${ }^{2}$

The spread of circulating tumor cells (CTCs) in the blood plays a major role in the initiation of metastases and tumor recurrence after surgery. ${ }^{3}$ The clinical relevance 
of detecting CTCs as a prognostic and/or surrogate marker of treatment response has been established in several cancer types such as breast cancer, ${ }^{4} \mathrm{CRC},{ }^{5}$ and prostate cancer. ${ }^{6}$

A multicenter prospective study including 456 patients with metastatic colorectal cancer (mCRC) demonstrated that CTC levels before treatment were an independent prognostic factor for progression-free survival (PFS) and OS. ${ }^{7}$ A metaanalysis performed on 12 studies of stage IV CRC provides the strongest level of evidence for the prognostic utility of CTCs. ${ }^{8}$ These studies confirm the association between CTCs in patients with metastatic disease and worse PFS and OS.

Most of these studies focus on the correlation of CTC enumeration with prognosis. ${ }^{9-13}$ However, recent studies showed that only enumerated CTCs were not enough to reflect the heterogeneous condition of tumors., ${ }^{3,14,15}$ CTCs disseminate from primary tumors by undergoing phenotypic changes that allow the cells to penetrate blood vessels. ${ }^{16}$ These changes are accompanied by a process described as epithelial-mesenchymal transition (EMT), which is a complicated process that plays an essential role in metastasis. ${ }^{17}$

Some recent reports have provided evidence that CTCs exhibit dynamic changes in epithelial and mesenchymal composition. ${ }^{18-20}$ Mesenchymal CTCs (mCTCs) are associated with metastasis and resistance to chemotherapy. The encourage future studies regarding the expression of EMT related markers in CTCs and cancer progressio

The family with sequence similarity (FAM172A), was first identified in huma lial cells in 2009. Then, several sty mem em $\mathrm{A}$ had estigated its functional relationship with or. Feng en found that FAM172A was down-regu,ated ang hepatocellular carcinoma patients. It play $\mathrm{an}$ important in cell cycle control and tumor cell oliferat n. ${ }^{21}$ The protein expression of FAM172A in a rect cancerous tissues is significantly lower thar in a cent tis. It suppressed the proliferative dentia nd pro apoptotic and invasive potentials colon cells. ${ }^{1,22}$ However, in papillary thyroid carcin (PTC), it has been found that FAM172A expression in can ous tissues was significantly higher than that in carcinoma adjocent tissues and normal thyroid tissues. FAM172A accelerated PTC cell proliferation via activation of the $p 38$ MAPK signaling pathway. ${ }^{23}$

As FAM172A is closely related to $\mathrm{CRC}$ proliferation and invasion, ${ }^{23,24}$ it would be highly interesting to detect FAM172A expression in CTCs to get a deeper understanding of the role FAM172A plays in EMT process.

The aim of this study was to discriminate different metastasis potentials of CTCs and explore FAM172A expression in individual CTCs to determine the correlations of CTC subgroups and FAM172A expression in CTCs with the commonest clinical and morphological variables of CRC patients.

\section{Methods}

\section{Patient samples and blood collection}

This prospective single-institution study enrolled 45 patients with the following criteria: 1) signed informed consent, 2) newly diagnosed nonmetastatic colon having histological diagnosis, 3) newly diagnosed mCRC, and 4) absence of other concomitant or previous malignant diseases.

Patients were recruited by The Fir Hospital of Wenzhou Medical Universit rrom Mar 2015 to December 2015. This study was a roved by ethical committee of The First \& Miated H vital o Wenzhou Medical University. All atients $p$ vided cen informed consent to participata in is s ay.

Blood sample were colh ed bef surgery or adjuvant chemotherap patients w carly stages and before palliative chemothera from those with advanced disease. Blood ampes $(5 \mathrm{~mL})$ drawn into heparinized tubes and tored at $4^{\circ} \mathrm{C}$ vithin 4 hours.

\section{CT identif cation}

throcyuswere removed using a red blood cell lysis buffer co an ammonium chloride $\left(\mathrm{NH}_{4} \mathrm{Cl}\right)$ and then transferred $\checkmark$ the filtration tube and filtered with the help of a pump valve. FTCs were isolated using a calibrated membrane with $8 \mu \mathrm{m}$ lameter pores. ${ }^{25}$

The cells on the membrane were hybridized for 2 hours, and unbound probes were washed three times with phosphatebuffered saline (PBS). Subsequently, samples were incubated with a preamplifier solution for 20 minutes and then incubated with an amplifier solution (three types of fluorescently labeled probes, which had been conjugated with the fluorescent dyes Alexa Fluor 594 [EpCAM and CK8/18/19], Alexa Fluor 488 [vimentin and twist], and Alexa Fluor 647 [CD45]). Finally, the cells were stained with 4',6-diamidino2-phenylindole (DAPI) for 5 minutes and then analyzed with a fluorescence microscope. ${ }^{18,19}$

The leukocytes were characterized as CD45+DAPI+ cells. CTCs were defined with the following three subgroups: 1) epithelial marker-positive CD45-DAPI+ cells (epithelial CTCs); 2) biophenotypic epithelial/mesenchymal marker-positive CD45-DAPI+ cells (biophenotypic CTCs); and 3) mesenchymal marker-positive CD45-DAPI+ cells (mCTCs).

\section{Statistical methods}

Correlation of CTCs with clinical variables was done by contingency table analysis using the chi-square test. 
Continuous data were compared using nonparametric tests (Mann-Whitney test for comparison between two groups and Kruskal-Wallis test for comparison among three or more groups). All analyses were conducted using SPSS 20.0. For all analyses, $P<0.05$ was considered statistically significant.

\section{Results}

\section{Patient demographics}

Blood samples for CTC assessment were taken from 45 consecutive patients with primary CRC. Clinical and morphological characteristics of the assessable 45 patients are summarized in Table 1. The median number of CTCs isolated was 4 (range $0-31$ ).

Table I Demographics of patients included in the study $(n=45)$

\begin{tabular}{|c|c|c|}
\hline Characteristics & $\mathbf{n}$ & $\%$ \\
\hline \multicolumn{3}{|l|}{$\overline{\text { Age }}$} \\
\hline$\leq 60$ years & 26 & 57.8 \\
\hline$>60$ years & 19 & 42.2 \\
\hline \multicolumn{3}{|l|}{ Gender } \\
\hline Male & 18 & 40 \\
\hline Female & 27 & 60 \\
\hline \multicolumn{3}{|l|}{ Tumor location } \\
\hline Colon & 30 & 66.7 \\
\hline Rectal & 15 & \\
\hline \multicolumn{3}{|l|}{ Tumor size } \\
\hline$\leq 5 \mathrm{~cm}$ & 32 & \\
\hline$>5 \mathrm{~cm}$ & 13 & \\
\hline \multicolumn{3}{|l|}{ Tumor grade } \\
\hline \multicolumn{3}{|l|}{ Low } \\
\hline \multicolumn{3}{|l|}{ Moderate } \\
\hline \multicolumn{3}{|l|}{ Vascular invasion } \\
\hline No & & 71.1 \\
\hline Yes & & 28.9 \\
\hline \multicolumn{3}{|l|}{ Depth of invasion } \\
\hline TI-T3 & & 46.7 \\
\hline $\mathrm{T} 4$ & 24 & 53.3 \\
\hline \multicolumn{3}{|c|}{ Lymphatic metastasis } \\
\hline No & 20 & 44.4 \\
\hline Yes & & 55.6 \\
\hline \multicolumn{3}{|l|}{ Distant metar } \\
\hline No & 39 & 86.7 \\
\hline Yes & 6 & 13.3 \\
\hline \multicolumn{3}{|l|}{ TNM stag } \\
\hline I & 5 & 11.1 \\
\hline II & 20 & 44.4 \\
\hline III & 14 & 31.1 \\
\hline IV & 6 & 13.3 \\
\hline \multicolumn{3}{|l|}{ CEA } \\
\hline$\leq 5 \mathrm{ng} / \mathrm{mL}$ & 24 & 53.3 \\
\hline$>5 \mathrm{ng} / \mathrm{mL}$ & 21 & 46.7 \\
\hline \multicolumn{3}{|l|}{$\mathrm{Ki}-67$} \\
\hline$\leq 60$ & 24 & 53.3 \\
\hline$>60$ & 21 & 46.7 \\
\hline \multicolumn{3}{|l|}{ CTC counts } \\
\hline$\geq \mathrm{ICTCs} / 5 \mathrm{~mL}$ & 34 & 75.6 \\
\hline$\geq 3 \mathrm{CTCs} / 5 \mathrm{~mL}$ & 28 & 62.2 \\
\hline
\end{tabular}

Abbreviations: TNM, tumor-node-metastasis; CEA, carcinoembryonic antigen; CTCs, circulating tumor cells.
mCTCs closely related to hematogenous metastasis

The CTCs could be classified into three subpopulations according to the EMT markers that expressed, including epithelial CTCs, biophenotypic CTCs, and mCTCs; typical photographs are shown in Figure 1.

Overall, the presence of $\geq 3 \mathrm{CTCs} / 5 \mathrm{~mL}$ was detected in 28 of 45 patients $(62.2 \%$ ), which was defined as CTC positive. mCTCs were found in 26 enrolled patients; $\geq 1 \mathrm{mCTCs} / 5 \mathrm{~mL}$ was defined as $\mathrm{mCTC}$ positive.

Correlation between typical arican thological variables and the presence of CT in blood s analyzed by chi-square test, ${ }^{26}$ which is sho in Table Correlation was not found among sitive CT and $y$ st of the clinicopathological fea es. On stage ( $\%$ in stages I-II, $75.0 \%$ in stage $\mathrm{IIl}-0.114$ nd carcinoembryonic antigen (CF level $(50 \%$ in $\mathrm{A} \leq 5 \mathrm{ng} / \mathrm{mL}, 76.2 \%$ in $\mathrm{CEA}>\mathrm{g} / \mathrm{h} \quad P=0.071$ related with positive CTCs, although it was in tatistically significant (Table 2).

Among CRC pai ts, mCTC percentage significantly hcreased alng with tumor progression; we observed significant ssociation between MCTC positivity and th develor dent of distant metastases in CRC patients. Signiticantly higher mCTC levels were detected in patients w. distant metastasis than in patients without distant metastasis ( $100 \%$ vs $51.3 \%, P=0.024)$. In addition, mCTCs were also closely related to vascular invasion. Our study showed that mCTCs were more commonly found in patients with vascular invasion $(84.6 \%$ vs $46.9 \%, P=0.020)$. There was also a clear association between the presence of mCTCs and depth of invasion and/or tumor-nodemetastasis stage, although it was not statistically significant (Table 2).

The significantly higher percentage of mCTCs in the more aggressive status prompts us to hypothesize whether mCTC detection can be a surrogate marker of tumor aggressiveness.

\section{FAMI72A gene expression in CTCs aggressively correlated with tumors}

Furthermore, in our platform, CTCs can be captured and then be used for further gene expression analysis. This is attractive because we can obtain genome information from the cancers via CTCs without invasive procedures and detect genetic change in real time, which has the potential to provide predictive information to guide the selection of therapy.

Recent report showed that FAM172A suppressed the proliferative and invasive potentials of CRC cell lines. ${ }^{22}$ Nevertheless, how FAM172A expressed in CTCs and their clinical value were still unknown. 

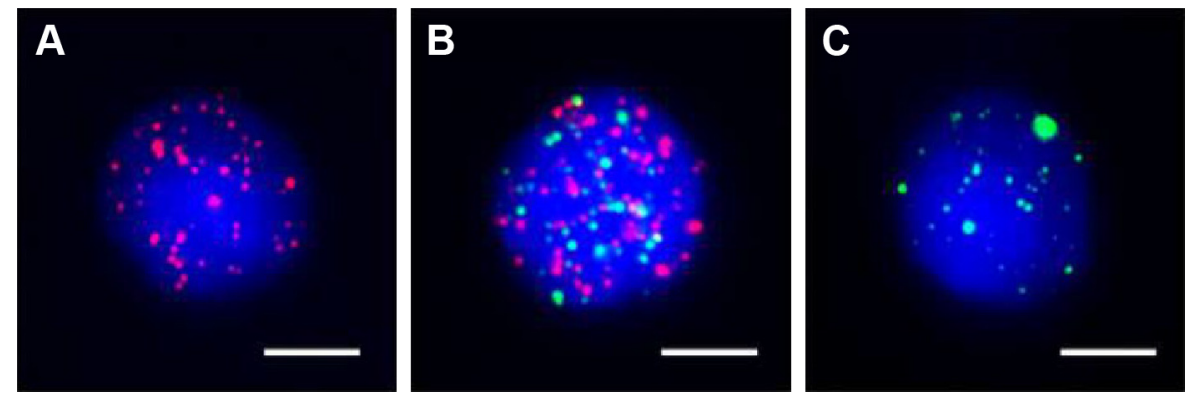

Figure I Representative images of three subgroups of CTCs isolated from patients with CRC, based on RNA-ISH staining of E (red dots) and M (green dots) markers. Notes: (A) Epithelial, (B) Biphenotypic, (C) Mesenchymal. The scale bar is $10 \mu \mathrm{m}$.

Abbreviations: CTCs, circulating tumor cells; CRC, colorectal cancer; RNA-ISH, RNA in situ hybridization; E, epithelial; M, mesenchymal.

Twenty-eight patients with CTC positivity $(\geq 3 \mathrm{CTCs} / \mathrm{mL})$ were enrolled for evaluating biomarker expression. FAM172A + CTC were detected in 20 of 28 patients $(71.4 \%)$. Photographs of CTCs with FAM172A expression are shown in Figure 2.

Table 2 Correlation among CTCs and clinical/morphological variables $(n=45)$

\begin{tabular}{|c|c|c|c|c|c|}
\hline Characteristics & n & $\begin{array}{l}\geq 3 \mathrm{CTCs} / \\
5 \mathrm{~mL}\end{array}$ & $P$-value & $\begin{array}{l}\geq 1 \mathrm{mCTCs} / \\
5 \mathrm{~mL}\end{array}$ & $P$-value \\
\hline Tumor location & & & 0.384 & & 70 \\
\hline Colon & 30 & 20 & & 18 & \\
\hline Rectal & 15 & 8 & & 8 & \\
\hline Tumor size & & & 0.460 & & \\
\hline$\leq 5 \mathrm{~cm}$ & 32 & 21 & & & \\
\hline$>5 \mathrm{~cm}$ & 13 & 7 & & & \\
\hline \multicolumn{6}{|l|}{ Tumor grade } \\
\hline Low & 8 & 6 & & & \\
\hline Moderate & 37 & 22 & & & \\
\hline \multicolumn{6}{|l|}{ Vascular invasion } \\
\hline No & 32 & 18 & & & \\
\hline Yes & 13 & & & 11 & \\
\hline Depth of invasion & & & & & 0.058 \\
\hline TI-T3 & & & & 8 & \\
\hline $\mathrm{T} 4$ & & & & 18 & \\
\hline Lymphatic m & & & & & 0.434 \\
\hline No & & & & 10 & \\
\hline Yes & & & & 16 & \\
\hline Distant metastas & & & 0.252 & & 0.024 \\
\hline No & & 23 & & 20 & \\
\hline Yes & & 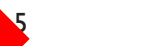 & & 6 & \\
\hline TNM stage & & & 0.114 & & 0.138 \\
\hline I-II & 25 & 13 & & 12 & \\
\hline III-IV & 20 & 15 & & 14 & \\
\hline CEA & & & $0.07 I$ & & 0.083 \\
\hline$\leq 5 \mathrm{ng} / \mathrm{mL}$ & 24 & 12 & & 11 & \\
\hline$>5 \mathrm{ng} / \mathrm{mL}$ & 21 & 16 & & 15 & \\
\hline Ki-67 & & & 0.299 & & 0.302 \\
\hline$\leq 60$ & 22 & 11 & & II & \\
\hline$>60$ & 23 & 17 & & 15 & \\
\hline
\end{tabular}

Abbreviations: CTCs, circulating tumor cells; mCTCs, mesenchymal circulating tumor cells; TNM, tumor-node-metastasis; CEA, carcinoembryonic antigen.
Previous studies have sho 1 wide olecular d cellular heterogeneity of CTCs fro he same types $f c$ cer and even from the same patient. ur res ch found nat the overall expression rate $0^{\circ} \mathrm{AM}$ in $\mathrm{CT}$ was $60.7 \%$, with $56.3 \%$ in epith CTCs, $58 \%$ biophenotypic CTCs, and $68.8 \%$ mC FAM17. expression in mCTCs was signicantly highe an that in epithelial CTCs, which imp' d that FAM172A may correlate with tumor malignancy, pro oting cance ell metastasis and invasion.

hypothesi was proved when the relationship between FAM1 expression and characteristics of CRC pay to was analyzed, which is shown in Table 3. We observed ignificant association between FAM172A expression and depth of invasion in CRC patients (68.1\% in $\mathrm{T} 1-\mathrm{T} 3$ vs $51.3 \%$ T4, $P=0.024)$. Besides, higher Ki-67 value showed higher FAM172A expression rate ( $71.3 \%$ in Ki-67 $\leq 60$ vs $48.8 \%$ in Ki-67 $>60, P=0.003)$. In addition, FAM172A expression rate in mCTCs is closely correlated with metastasisassociated clinicopathological features such as vascular invasion (78.9\% vs $37.5 \%, P=0.007)$ and depth of invasion $(77.3 \%$ in $\mathrm{T} 1-\mathrm{T} 3$ vs $33.3 \%$ in $\mathrm{T} 4, P=0.004)$ in $\mathrm{CRC}$ patients, which meant that combining CTC subgroups with FAM172A gene expression may enhance clinical prediction of CRC metastasis.

\section{CTC/FAMI72A detection may predict high-risk subgroups in stage II CRC}

For patients diagnosed at stage II, correlations between CTCs and prognostic subgroups were analyzed. CTC detection would be an easy and reproducible test to select high-risk stage II patient candidates for adjuvant chemotherapy. At the present time, high-risk stage II is defined by clinical/ pathological prognostic factors such as T4, perforation, acute bowel obstruction, undifferentiated tumors, high preoperative CEA levels, or $<12$ lymph nodes removed. ${ }^{26}$ 


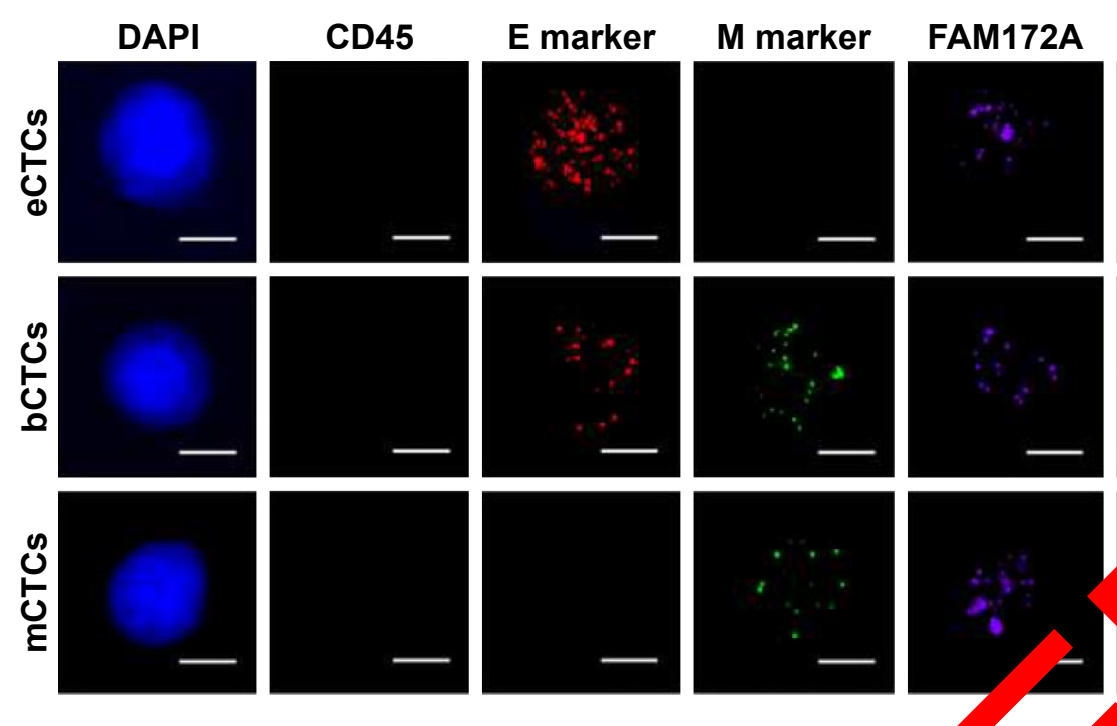

Figure 2 Representative images of FAMI72A expression in three subgroups of CTCs isolated from patients with based of NA-ISH staining of E (red dots), M (green dots), and FAMI72A (purple dots) markers.

Note: The scale bar is $10 \mu \mathrm{m}$.

Abbreviations: CTCs, circulating tumor cells; CRC, colorectal cancer; CD45, leukocyte common antigen; D 4',6-diamidino-2 nylip e; RNA-ISH, RNA in situ hybridization; E, epithelial; M, mesenchymal; eCTCs, epithelial circulating tumor cells; bCTCs, biophenotypic circulatin mo, "ss; mCTCs, mes mal circulating tumor cells.

Table 3 Demographics of patients with CTCs $\geq 3$ used for analysis of FAMI72A expression rate with clinicopathological features $(n=28)$

\begin{tabular}{|c|c|c|c|c|}
\hline Characteristics & $\begin{array}{l}\text { FAMI72A } \\
\text { expression } \\
\text { in CTCs (\%) }\end{array}$ & $P$-value & $\begin{array}{l}\text { FAMI72A } \\
\text { expression in } \\
\text { mCTCs (\%) }\end{array}$ & Prvalue \\
\hline Tumor location & & 0.151 & & 0.9 \\
\hline Colon & 64.0 & & & \\
\hline Rectal & 52.6 & & & \\
\hline Tumor size & & & & \\
\hline$\leq 5 \mathrm{~cm}$ & 56.6 & & & \\
\hline$>5 \mathrm{~cm}$ & 68.0 & & & \\
\hline Tumor grade & & & & $0.84 I$ \\
\hline Low & 75.0 & & 60.0 & \\
\hline Moderate & 69.3 & & & \\
\hline Vascular invasion & & 0.619 & & 0.007 \\
\hline No & & & 37.8 & \\
\hline Yes & & & 78.9 & \\
\hline Depth of invasion & & 0.0 & & 0.004 \\
\hline TI-T3 & & & 33.3 & \\
\hline $\mathrm{T} 4$ & & & 77.3 & \\
\hline Lympha & & 0 & & 0.708 \\
\hline No & & & 52.6 & \\
\hline Yes & 55.8 & & 58.3 & \\
\hline Distant me & & 0.297 & & 0.190 \\
\hline No & 58.1 & & 50.0 & \\
\hline Yes & 69.6 & & 72.7 & \\
\hline TNM stage & & 0.378 & & 0.658 \\
\hline I-II & 63.8 & & 52.4 & \\
\hline III-IV & 57.1 & & 59.1 & \\
\hline CEA & & 0.082 & & 0.780 \\
\hline$\leq 5 \mathrm{ng} / \mathrm{mL}$ & 60.4 & & 55.6 & \\
\hline$>5 \mathrm{ng} / \mathrm{mL}$ & 58.8 & & 60.0 & \\
\hline Ki-67 & & 0.003 & & 0.553 \\
\hline$\leq 60$ & 48.8 & & 52.0 & \\
\hline$>60$ & 71.3 & & 61.1 & \\
\hline
\end{tabular}

Abbreviations: $\mathrm{CTCs}$, circulating tumor cells; mCTCs, mesenchymal circulating tumor cells; TNM, tumor-node-metastasis; CEA, carcinoembryonic antigen.
The correlation butween CTCs or FAM172A detecon and pros ostic subgroups in stage II CRC is shown in ble 4 . We und that both $\mathrm{mCTC}$ positivity rate $(66.7 \%$ vs $=0.199)$ and FAM172A expression positivity te $(54.5 \%$ vs $22.2 \%, P=0.142)$ in high-risk groups were higher than those in low-risk groups, although there were no statistically significant differences between them.

Limited by sample quantity, although our study had not proven confident evidence to discriminate high/low risk of prognostic subgroups, the potential of CTCs to better aid in selection of high-risk group patients has potential clinical value, as there is controversial evidence regarding the benefits of chemotherapy, which is currently prescribed based on clinicopathological criteria.

\section{Discussion}

Blood sampling is less invasive, less painful, easy to perform, and better accepted sampling. For monitoring the efficacy of therapy, detection and characterization of CTCs by blood sampling might be a new option for therapeutic interventions. CTC enumeration via the CellSearch ${ }^{\mathrm{TM}}$ system is approved by the US Food and Drug Administration for use as an aid in monitoring patients with mCRCs. The presence of $\geq 3$ CTCs for CRC prior to treatment is associated with decreased PFS and OS and is prognostic, regardless of the therapy used.

This enrichment approach involves the attachment of magnetic particles to EpCAM expression on the cell surface for separation of CTCs from the sample using magnetic fields. 
Table 4 CTCs/FAMI72A detection and prognostic subgroups in stage II colorectal cancer

\begin{tabular}{|c|c|c|c|c|c|c|}
\hline $\begin{array}{l}\text { Prognostic } \\
\text { subgroups }\end{array}$ & $\begin{array}{l}\text { CTCs positivity } \\
\text { rate }(\%)\end{array}$ & $P$-value & $\begin{array}{l}\text { mCTCs positivity } \\
\text { rate }(\%)\end{array}$ & $P$-value & $\begin{array}{l}\text { FAMI72A expression } \\
\text { positive (\%) }\end{array}$ & $P$-value \\
\hline Low risk & $5(50.0)$ & 0.653 & $3(37.5)$ & 0.199 & $2(22.2)$ & 0.142 \\
\hline High risk & $6(60.0)$ & & $8(66.7)$ & & $6(54.5)$ & \\
\hline
\end{tabular}

Abbreviations: CTCs, circulating tumor cells; mCTCs, mesenchymal circulating tumor cells.

Although frequently used, the CellSearch system needs to be interpreted with caution. ${ }^{27}$

The presence of nontumor epithelial cells within the bloodstream may contribute to false-positive results. It has been noted that patients with benign disease of the colon exhibited "tumor cells" as detected with the CellSearch system (11.3\%). ${ }^{28}$ Besides, this approach would miss CTCs that have low levels of EpCAM expression and fail to detect the most aggressive CTC subpopulation, which may have undergone EMT. ${ }^{29}$ For example, the rarity of CTCs in early CRC was illustrated in a study of 20 consecutive patients undergoing curative resection for stages I-III CRC. ${ }^{30}$ The detection rate using CellSearch system was 5\% in the preoperative samples, using a cutoff of $2 \mathrm{CTCs} / 7.5 \mathrm{~mL}$. Although the cascades of cancer metastasis formation are not fully understood, the EMT process is believed to have a great role in these cascades. ${ }^{31}$

In this study, we have taken the above into consideration In order to minimize CTC losses as much as isolated CTCs via a filter-based method, aich e raps nonblood-derived cells because of their oger inflexibility. Later, an RNA in situ fridis in (RNAISH) method based on the branch NA signal o plification technology was used to cussify a CTCs according to EMT markers and an codbody cockta consisting of EpCAM, CK8/18/19, vi antin, ap twist was used to identify the CTCs. CD45 mark wer ased to exclude hematopoietic cells. ${ }^{19}$

Classifyir CTCS y EM ers helps to identify the more agg ive $C$ monopulion and provides useful evidence for $\mathrm{d}$ nining an appropriate clinical approach. ${ }^{32}$ Therefore, our ro rch presented here has the potential to provide better prognustic information on the probability of metastasis in early-stage cancer patients.

CRC is the third leading cause of cancer death in China. ${ }^{1}$ The last few years have seen a significant expansion in the number of available systemic therapies to treat mCRC. ${ }^{33}$ However, with increasing options comes greater complexity in decision making. A biomarker that could be obtained in a noninvasive manner to guide therapy would thus be of great potential clinical utility.
CTCs hold great potential as liquid biopsies to prognosticate disease and guide treatment in CRCs. It is worthwhile to study their important role in determining the genome information of tumor metastasis, providing bi detection for targeted therapies and determinati of drug ro tance..$^{34,35}$ FAM172A had shown important ss in regul ng CRC proliferation and metasta In this ork, a gnificant association between $\mathrm{m} C$ posit ty and development of distant metastase in $\mathrm{Cp}$ cents war observed. Greater number of patie with d. nt me stasis in CRC were identified tha without dis metastasis.

In addition, $\mathrm{mCT}$ were also closely related to vascular invas an mCTC po jity rate and FAM172A expressior positivity rate in high-risk groups were higher than tho in low-risk roups. Combining CTC subgroups with FAM 2A gene pression may enhance clinical prediction \& CRC murustasis, which could help us better understand th anism of tumor metastasis involved in it.

\section{Conclusion}

TCs from 45 primary CRC patients were enriched by blood filtration. The RNA-ISH method was used to identify and discriminate subgroups of CTCs, and FAM172A expression in individual CTCs was measured. The $\mathrm{mCTC}$ positivity rate and FAM172A expression positivity rate were obviously higher in high-risk groups, suggesting that FAM172A may correlate with tumor malignancy. Our research proved that CTCs could serve as feasible surrogate samples to detect gene expression as a predictive biomarker for tumor evaluation, which provides a more accurate route for prediction of high $\mathrm{CRC}$ risk in future.

\section{Disclosure}

The authors report no conflicts of interest in this work.

\section{References}

1. Chen W, Zheng R, Baade PD, et al. Cancer statistics in China, 2015. CA Cancer J Clin. 2016;66(2):115-132.

2. Linnekamp JF, Wang X, Medema JP, Vermeulen L. Colorectal cancer heterogeneity and targeted therapy: a case for molecular disease subtypes. Cancer Res. 2015;75(2):245-249.

3. Paterlini-Brechot $P$, Benali NL. Circulating tumor cells (CTC) detection: clinical impact and future directions. Cancer Lett. 2007;253(2):180-204. 
4. Cristofanilli M, Budd GT, Ellis MJ, et al. Circulating tumor cells, disease progression, and survival in metastatic breast cancer. $N$ Engl J Med. 2004;351(8):781-791.

5. Cohen SJ, Punt CJ, Iannotti N, et al. Relationship of circulating tumor cells to tumor response, progression-free survival, and overall survival in patients with metastatic colorectal cancer. J Clin Oncol. 2008;26(19): 3213-3221.

6. de Bono JS, Scher HI, Montgomery RB, et al. Circulating tumor cells predict survival benefit from treatment in metastatic castration-resistant prostate cancer. Clin Cancer Res. 2008;14(19):6302-6309.

7. Meropol N, Cohen S, Iannotti N, et al. Circulating tumor cells (CTC) predict progression free (PFS) and overall survival (OS) in patients with metastatic colorectal cancer. Paper presented at: ASCO Annual Meeting Proceedings; 2007; Chicago, USA.

8. Koerkamp BG, Rahbari NN, Büchler MW, Koch M, Weitz J. Circulating tumor cells and prognosis of patients with resectable colorectal liver metastases or widespread metastatic colorectal cancer: a meta-analysis. Ann Surg Oncol. 2013;20(7):2156-2165.

9. Bhaumik P, Gopalakrishnan C, Kamaraj B, Purohit R. Single nucleotide polymorphisms in microRNA binding sites: implications in colorectal cancer. ScientificWorldJournal. 2014;2014:547154.

10. Kumar A, Rajendran V, Sethumadhavan R, Purohit R. Evidence of colorectal cancer-associated mutation in MCAK: a computational report. Cell Biochem Biophys. 2013;67:837-851.

11. Ambuj K, Rituraj P. Use of long term molecular dynamics simulation in predicting cancer associated SNPs. PLoS Comput Biol. 2014;10(4): e1003318.

12. Qian K, Zhang J, Lu JB, et al. FAM172A modulates apoptosis and proliferation of colon cancer cells via STAT1 binding to its promoter. Oncol Rep. 2016;35(3):1273-1280.

13. Ambuj K, Vidya R, Rao S, et al. Identifying novel oncogenes: a machine learning approach. Interdiscip Sci. 2013;5(4):241-246.

14. Chinen LTD, de Carvalho FM, Rocha BMM, et al. Cytokera CTC counting unrelated to clinical follow up. J Thorac Dis. 20 5(5). 593-599.

15. Li H, Song P, Zou B, et al. Circulating tumor cell an esophageal squamous cell carcinoma using epith mar and -independent approaches. Medicine. 20

16. Chaffer CL, Weinberg RA. A perspectiv Science. 2011;331(6024):1559-1564.

17. Lamouille S, Xu J, Derynck R. M cular mechà mesenchymal transition. Nat Re Gell Biol. 201 (3):178.

18. Yu M, Bardia A, Wittner BS, G, r. Circu, ng breast tumo cells exhibit dynamic changes in epith $\mathrm{l}$ and mesenc, al composition. Science. 2013;339(6119):580

19. Wu S, Liu S, Liu 7 al. Clas cation of circulating tumor cells by epithelial-mesen nal tra con markers. PLoS One. 2015;10(4): e0123976.

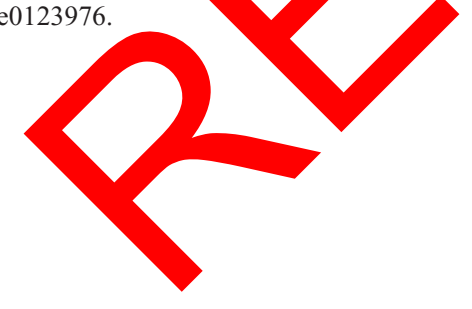

20. Li Y, Xu S, Li J, et al. Epithelial-mesenchymal transition markers expressed in circulating tumor cells in hepatocellular carcinoma patients with different stages of disease. Cell Death Dis. 2013;4(10):e831.

21. Feng Z, LiH, Liu S, Cheng J, Xiang G, Zhang J. FAM172A induces S phase arrest of HepG2 cells via Notch 3. Oncol Rep. 2013;29(3):1154-1160.

22. Cui C, Ye L, Huang Z, Huang S, Liu H, Yu J. FAM172A is a tumor suppressor in colorectal carcinoma. Tumor Biol. 2015;37:1-10.

23. Li MF, Zhang R, Guo MG, et al. FAM172A protein promotes the proliferation of human papillary thyroid carcinoma cells via the $\mathrm{p} 38$ mitogen-activated protein kinase pathway. Mol Med Rep. 2016;13(1): 353-358.

24. Cui C, Ye L, Huang Z, Huang S, Liu H, Yu J. FAM172A is a tumor suppressor in colorectal carcinoma. Tumor Biol. 2016;37:6501-6510.

25. Ma Y-C, Wang L, Yu F-L. Recent advances and prospects in the isolation by size of epithelial tumor cell nethodology. Technol Cancer Res Treat. 2013;12(4):295

26. Sastre J, Maestro M, Puente J, et Circulating tum fells in colorectal cancer: correlation with clinical an thological val bles. Ann Oncol. 2008;19(5):935-938.

27. Farace F, Massard $C$ imond N, et a comparison of CellSearch and IS ror circu ing tumou detection in patients with metastatic arc nas J Cancer 2011;105(6):847-853.

28. Pearl ML, $\mathrm{Zh}$ Q, Yang. 1. Prognos analysis of invasive circulating tumor cel CTCs) in epit al oy an cancer. Gynecol Oncol. 2014; 134(3

29. Arya SK, Lim B, hman ARA. Enrichment, detection and clinical signifianse of circulatì. vmor cells. Lab Chip. 2013;13(11):1995-2027. Aarangham JE, Gron ?, Winter M, Hewett PJ, Price TJ, Thierry B. Detection and clinical significance of circulating tumor cells in colorectal cancer $-\quad$ years of progress. Mol Med. 2015;21(suppl 1):S25.

Wan L, Pan K, Kang Y. Tumor metastasis: moving new biological 'sights in the clinic. Nat Med. 2013;19(11):1450-1464.

32. Arier A, Vielh P, Perez-Moreno P, Planchard D, Soria J, Farace F. Detection of circulating tumour cells with a hybrid (epithelial/ senchymal) phenotype in patients with metastatic non-small cell lung cancer. Br J Cancer. 2011;105(9):1338-1341.

33. Van Cutsem E, Cervantes A, Nordlinger B, Arnold D. Metastatic colorectal cancer: ESMO Clinical Practice Guidelines for diagnosis, treatment and follow-up. Ann Oncol. 2014;25(suppl 3):iii1-iii9.

34. Yokobori $\mathrm{T}$, Iinuma $\mathrm{H}$, Shimamura $\mathrm{T}$, et al. Plastin 3 is a novel marker for circulating tumor cells undergoing the epithelial-mesenchymal transition and is associated with colorectal cancer prognosis. Cancer Res. 2013;73(7):2059-2069.

35. Wang J-Y, Wu C-H, Lu C-Y, et al. Molecular detection of circulating tumor cells in the peripheral blood of patients with colorectal cancer using RT-PCR: significance of the prediction of postoperative metastasis World J Surg. 2006;30(6):1007-1013.

\section{Publish your work in this journal}

OncoTargets and Therapy is an international, peer-reviewed, open access journal focusing on the pathological basis of all cancers, potential targets for therapy and treatment protocols employed to improve the management of cancer patients. The journal also focuses on the impact of management programs and new therapeutic agents and protocols on

\section{Dovepress}

patient perspectives such as quality of life, adherence and satisfaction. The manuscript management system is completely online and includes a very quick and fair peer-review system, which is all easy to use. Visit http://www.dovepress.com/testimonials.php to read real quotes from published authors. 